\title{
Reasons Not to Discuss and Challenges of Parent- young Communication and Associated Factors on Sexual and Reproductive Health Among Parents and Students in North Gondar Zone, Northwest Ethiopia, 2021, Mixed Qualitative Study
}

Yohannes Wobie Wondimhunegn ( $\square$ yohanneswobie@gmail.com )

Mizan-Tepi University https://orcid.org/0000-0001-8498-7436

Alemnew Wale Tegegne

Mizan-Tepi University

Aychew Kassie Gidafie

Mizan-Tepi University

Desalegn Girma Mamo

Mizan-Tepi University

Abinet Abebe Zewdu

Mizan-Tepi University

Zinie Abita Mengie

Mizan-Tepi University

Bezie Kebede Zelalem

Mizan-Tepi University

Research

Keywords: young, communication, sexual, reproductive, health, Mizan Ethiopia,2021

Posted Date: August 26th, 2021

DOl: https://doi.org/10.21203/rs.3.rs-815767/v1

License: (c) (i) This work is licensed under a Creative Commons Attribution 4.0 International License.

Read Full License 


\section{Abstract}

Introduction

Parent - young communication on sexual and reproductive health is one potential source of sexual and reproductive health information for young people. Lack of parent - young people communication was a serious problem in developing countries that resulted in emotional distress, lower self-esteem, school problems, drug use, and sexual risk behaviors. Assessing the the reasons and challenges of parents to young people communication about a sexual and reproductive health issue is the most effective way to prevent preexisting misbehavior in young people.

\section{Objective}

The study aimed to assess reason not to discuss and challenges of parent-young communication, and associated factors on sexual and reproductive health among parent living with young in North Gondar zone, northwest Ethiopia 2021.

\section{Methods}

A Community based cross-sectional mixed qualitative study was conducted on 1000 parents of youngs for quantitative and 2FGD and 25 in-depth interviews were included with a diversity of parents and students. Data were collected using a pre-tested and semi-structured questionnaire through face-to-face interviews, FGD, and in-depth interviews. A bivariate and a multivariable logistics regression model was fitted for the quantitative part and individual in-depth interview and focus group discussion will be taperecorded after verbal consent will be granted and finally translated and transcribed by the data collectors. Thematic analysis will be used to analyze the qualitative data based on emerging themes and subthemes in line with the study objectives.

Result

According to this study parent to young communication was found to be $11.4 \%$ ( $95 \%$

$\mathrm{Cl}: 9.5,13)$. Multivariable analysis revealed that, residence ( $A O R=2.195 \% \mathrm{Cl} 1.15,9.34)$, sex (AOR=2.4,95\% $\mathrm{Cl} 2.11,4.33)$, knowledge ( $\mathrm{AOR}=3.8,95 \% \mathrm{Cl} 2.7,6.34)$, attitude( $\mathrm{AOR}=2.2,95 \% \mathrm{Cl} 1.44,4.32)$ Father's educational status $(A O R=4.3,95 \% \mathrm{Cl} 1.8,4.56)$, mother educational status ( $A O R=2.4,95 \% \mathrm{Cl} 1.23,4.12)$ number of children ( $\mathrm{AOR}=3,95 \% \mathrm{Cl} 2.6,4.74)$ and age $(\mathrm{AOR}=3.22,95 \% \mathrm{Cl} 2.8,4.9)$ were statistically significant associated factors on parent to young people communication.

Conclusion and recommendation

parent to young communication was low in this study as compared to other studies done in different pockets of Ethiopia. Successively, promotion of parent to young people communication and addressing the importance of parent to young people communication to all parents along with HEW was recommended 


\section{Plain English Summary}

Globally more than one-fourth of the total population is within the age range of 10 and 24 years old, from this $86 \%$ of them are living in developing countries. More than $60 \%$ of young people aged $15-24$ years were living with HIV world widely, and they also account for $58 \%$ of newly acquired HIV infections. Lack of parent to young communication would result in emotional distress self-esteem, reproductive and sexual health problems, drug use, and sexual risk behaviors but having good communication will increase utilization of contraceptives and condoms, delay early( sexual intercourse, marriage, and pregnancy having such problems in the country widely studies are limited and the existing studies focus on the associated factors and magnitudes of sexual and reproductive health of the young and study design is cross-sectional. But this study was a mixed qualitative study by design as well as adds the following two main points over the previous studies.

- The challenge of communication towards sexual and reproductive health

- The reasons not to discuss sexual and reproductive health and the respondents

Respondents were asked about knowledge, attitude, and practice of communication regarding sexual and reproductive health. From 1000 respondents only 114 (11.4\%) were communicate about sexual and reproductive health. Reasons and challenges of communication were addressed qualitatively using 68 participants. Promotion of parent to young people communication and addressing the importance of parent to young people communication to all parents along with health extension worker was recommended.

\section{Introduction}

Glovally more than a quarter of the population is between the ages of 10 and 24 years, with $86 \%$ living in less developed countries. Parent to young people communication on a sexual and reproductive health issue is one potential source of sexual and reproductive health information for young people. Parents and young people make decisions towards sexual and reproductive health issues mainly on contraception, pregnancy, childbirth, teenage pregnancy, and abortion in the context of many personal and cultural factors[1-3].

Teenage who live in a stable family and discuss sexuality and reproductive health issue is more likely to remain sexually abstinent, postpone intercourse, have one partner, and use contraception[4]

Globally more than $60 \%$ of young people aged $15-24$ years were living with HIV, and they also account for $58 \%$ of newly acquired HIV infections [5].

Men and women who equate masculinity and feminize respectively were risk-taking and sexual dominance as well more likely to have (multiple partners, STI and negative attitudes towards condom use)[6] 
In Ethiopia, over $63 \%$ of the total populations were below the age of 25 years and young people (10-24) year were account for about $25 \%$ of the total population. The sexual and reproductive health of these young people were affected by Gender inequality, sexual coercion, and early marriage, high level of teenage pregnancy, unsafe abortion, and sexually transmitted infection including HIV AIDS and further complicated by limited access to reproductive health information and good quality adolescent and youthfriendly reproductive health services in the country. Besides the very low health-seeking behavior of young people, the existing health service is an adult center[7, 8]

Although the government has identified the $\mathrm{RH}$ of young people as one of the priority areas in The National RH Strategy, still not put into practice[9].

Lack of parent to young people communication will result in emotional distress, lower

self-esteem, reproductive and sexual health problem, drug use, and sexual risk behaviors but having good communication will increase utilization of contraceptive and condom, delay early( sexual intercourse, marriage, and pregnancy)[10]

A study was done from national representative Ethiopian demography and health survey indicate that nearly one in three (33\%) births was unintended and the burden of unintended births in Ethiopia falls more heavily on young[11]

As two studies in wolitaSodo University, female students show that abortion, self-reporting STI and sexual intercourse with commercial sex workers were $65 \%, 19.5 \%$, and $13.9 \%$ respectively $[12,13]$

In similar studies in 3 areas of the Amahara region in Giga $56.3 \%$ of the students were practicing sexual intercourse before 18 years of birthday and most of them had no parental discussion about SRH. From Bahirdar secondary school students, the prevalence of STI was $13.1 \%$. The risk of this much STI is multiple sexual partners, poor parental discussion, and being students and in Gondar secondary school students the knowledge of STI was ranged $39 \%$ to $45.6 \%$ which is very low as a result of a poor parent to young people communication on $\mathrm{SRH}[14-16]$.

Having such reproductive and sexual health burden of the young people (10-24) years, there was limited evidence regarding it in the study area and existing studies were institutional-based, which is not focused on the parental factor of a parent to young people communication towards sexual and reproductive health issue and the challenges and reason of parent to young communication is not well addressed

So Seriousness of sexual and reproductive health of young people like STI and unsafe abortion including HIV AIDS and the above difference in study setup is the intention of study by conducting a communitybased study and focusing directly on powerful decision-maker parents living with their young(10 -24) years.

Parent - young people's discussion about sexual and reproductive health issues is very helpful to put the national RH strategy of the young people into practice. 


\section{Methods}

\section{Method}

A community-based cross-sectional mixed qualitative study was conducted from September 5 to January 30, 2021, in North Gondar. North Gondar is located $676 \mathrm{~km}$ away from Addis Ababa, the capital city of Ethiopia. In the zone, there are 16 wards, from 16 wards 6 of them is urban and the remaining are rural words

All parents of young people living with young people in the North Gondar Zone were the source population.

The sample size for the study population was determined with single proportion formula and factors using Epi Info Stat Calc version 7.2.1 population survey by taking assumptions of population size $>10,000,95 \%$ confidence interval, the proportion of parent to young people communication (25.3\%)in a previous study[17], margin of error $5 \%$, design effect 2 and non-response rate $10 \%$ and for the qualitative part we take the sample based on rule thump. With this, the sample size becomes 1000 for quantitative study and 68 individuals for qualitative study as 2 FGD, each FGD had 8 individuals and 25 in-depth interviews included in the study. A multi-stage sampling technique was employed. First; a stratified sampling technique was used to select rural and urban areas. In the zone there were 50,000 eligible households, 30,000 were in rural and 20,000 were in urban so that by proportional allocation $1000 * 30000 / 50000=600$ eligible $\mathrm{HH}$ for rural and $1000 * 20000 / 50000=400$ eligible $\mathrm{HH}$ for urban were included. Then from 16 woredas, 8 woredas were taken as a cluster.

The questionnaire was adapted from related literature [17-19]. The English version of the questionnaire was translated into the Amharic version than to the local language for better understanding to both data collectors and respondents. Consistency was checked by translating to the Amharic version then back to the English version by languages experts. Data were collected using a pre-tested and semi-structured questionnaire.

4puplic health, 4 nurses, and 4 Midwifery were recruited for data collectors we recruited as well 4 mater public health was the supervisor. Before the data collection, the data collectors and supervisors were trained. The questionnaire was pre-tested on $5 \%$ of the sample size were done in near woredas.

The code was given to the questionnaires and $\mathrm{HH}$ during the data collection period and any identified error was traced back using the codes.

Data were entered and cleaned using Epi Info 7.2.1 software and exported to SPSS version 25 for analysis.

\section{Operational and term definitions}


Parent to young people communication -- parents discussing at least one sexual and reproductive health issue in the last six month [17, 19-21]

Eligible Household---the households in which the parents live with young people (10-24) years

Parents----in this study denote biological mother/father and Parent- figure with whom the adolescents were primarily living the last six months before the study period[22].

Biological parent---is a birth parent [23].

Adequate knowledge-scoring means and above from knowledge related questions

Inadequate knowledge--scoring below mean from knowledge related questions

Good attitude-_--scoring means and above from attitude related questions $\quad[19,24]$

Poor attitude-_-_-scoring below mean from attitude related questions

Parent-figure-is the ideal parent example( adoptive, grandparent)[25].

\section{Results}

\section{Socio-demographic characteristic of the respondents}

A total of 1000 parents who were living with their young in the last 12 months were interviewed, out of these 600 were in rural and the remaining were urban by a residence with a response rate of $98 \%$. The mean ages of the participants were $42.5 \pm S D$ of 4.2 years. The majority of the religious were orthodox(81.4\%) followed by Muslim(14\%) and protestant(4.6\%) and $85.5 \%$ of the respondents were Amahara by ethnicity. The other least accountswere Tigray and Oromo, $12 \%$ and $3.5 \%$ respectively. Regarding marital status and living arrangement $61.2 \%, 18.8 \%, 11.4 \%$, and $8.6 \%$ were living together, living apart, divorced, and widowed respectively. Near to $50 \%$ of the women(49\%) and men(47.4\%), respondents were housewives and farmers See blow (table-1).

Table 1: Socio-demographic characteristics of the respondents in North Gondar, North West Ethiopia, $2021(n=1000)$ 


\begin{tabular}{|c|c|c|c|}
\hline Variable & & Frequency & Percent (\%) \\
\hline \multirow[t]{2}{*}{ Residence } & Urban & 400 & 40 \\
\hline & Rural & 600 & 60 \\
\hline \multirow[t]{2}{*}{ Sex } & Male & 506 & 50.6 \\
\hline & Female & 494 & 49.4 \\
\hline \multirow[t]{3}{*}{ Age } & $23-34$ & 390 & 39 \\
\hline & $35-45$ & 410 & 41 \\
\hline & $>45$ & 200 & 20 \\
\hline \multirow[t]{3}{*}{ Number of child } & $1-2$ & 352 & 35.2 \\
\hline & $3-5$ & 498 & 49.8 \\
\hline & $>5$ & 150 & 15 \\
\hline \multirow[t]{2}{*}{ Ethnicity } & Amahara & 845 & 84.5 \\
\hline & Oromo and Tigray & 155 & 15.5 \\
\hline \multirow[t]{4}{*}{ Living arrangement of the parents } & Living together & 612 & 61.2 \\
\hline & Living apart & 188 & 18.8 \\
\hline & Divorced & 114 & 11.4 \\
\hline & Widowed & 86 & 8.6 \\
\hline \multirow[t]{2}{*}{ Religion } & Orthodox & 814 & 81.4 \\
\hline & Muslim and protestant & 186 & 18.6 \\
\hline \multirow[t]{4}{*}{ Educational status of the mother } & Unable to read and write & 60 & 6 \\
\hline & Read and write & 140 & 14 \\
\hline & Primary and secondary education & 250 & 25 \\
\hline & Diploma and above & 44 & 4.4 \\
\hline \multirow[t]{4}{*}{ Educational status of the father } & Unable to read and write & 30 & 3 \\
\hline & Read and write & 170 & 17 \\
\hline & Primary and secondary education & 260 & 26 \\
\hline & Diploma and above & 46 & 4.6 \\
\hline \multirow[t]{2}{*}{ Occupation of the mother } & House wife & 350 & 35 \\
\hline & Gov.t and private employee & 50 & 5 \\
\hline
\end{tabular}




\begin{tabular}{|llll|}
\hline \multirow{2}{*}{ Occupation of the father } & Merchant & 64 & 6.4 \\
\cline { 2 - 3 } & Daily labor & 30 & 3 \\
\hline Farmer & 300 & 30 \\
\hline Gov.t and private & 120 & 12 \\
\hline Merchant & 70 & 7 \\
\hline Daily labor & 16 & 1.6 \\
\hline
\end{tabular}

\section{communication on a sexual and reproductive health issue}

The prevalence of parent to young people communication was found to be $114(11.4 \%)(95 \% \mathrm{Cl}$ : 9\%, $13.4 \%$ ). From this $86.84 \%$ were communicate about the sexually transmitted disease the remaining $6.14 \%, 4.30 \%$, and $2.63 \%$ were about family planning, unsafe sexual intercourse, and unwanted pregnancy respectively (figure 1) and From these respondents, $100(87.7 \%)$ were communicating about abstinences but only the remeaning $2(1.75 \%), 4(3.5 \%), 5(4.38 \%)$ and $3(2.63 \%)$ communicated about longacting family planning, condom use, injectable and COC respectively (figure-2). Regarding sexual transmitted diseases majority of them were communicating about HIV ADIS 95 (83.3\%) and the rest were Gonoreah, Chancroide, and syphilis(figure 3)

\section{Main theme 1 Commnucationchalelnges and reasons not to discussing}

\section{Sub-theme 1.1Community norms and values}

"In our culture discussing or communicating regarding sexual and reproductive health is forbidden and rejected at the community level. Even when the younger female child starts her nonsense, she afraid to share with her family rather she wants to be live alone"( 67,70 years old men and,40,47,50 years old women). "If the young child is seen for a long time with the opposite sex before marriage, they punish by the family and considered them as hopes, misbehaving, visionless and untrusted to family and the community as well they stigmatized by the society as a whole"(the description of 46,58 , and 36 years old women and 59,72,66 and 55 years old men). "Parent to young communication on the sexual issue is not raised in the family. such information sharing with the child is considered to be out the norm and culture of the community"( explained by $21,24,19$, and 20 years old female young).

"My mother always advises me about early sexual intercourse and its impact to the coming time and one male young said that we male individuals are ignored this is due to the parents do not worry about boys because boys are not pregnant as well not forced by girls" (this is the idea of 23 years old female and 19 years old male respectively)."In the second focus group discussion, communicating the sexual issue with the young child is not good, this may expose the young to early sexual intercourse. For example, if told to my young child to the condom when he needs sexual intercourse, automatically she or he starts the activities, better to avoid It" ( 42 years old mother). On the other hand, mother 2 explains as communicating regarding sexuality and reproductive health with the young has a positive impact on my 
child towards his or her education and life but the young afraid of such ideas( 46 years old mother). Two men describe parent to young people communication on sexual and reproductive as meaningless rather than telling them to do sexual practice( 48 and 67 years old men).

\section{Sub-theme 1.2 Fear of both the parent and the youngs}

"Parent to young people communication on sexual and reproductive health is very vital but it is so difficult to communicate the sexuality issue to the younger child because the child may shy and not accept our ideas"( 3 women and 2 men in the age ranged 30 to 42 years old)." we parents are afraid to discuss such like sexuality issues especially to our female child because our child may consider us as pushing agent and afraid to reach a common understanding"(32 and 46 years old women and men respectively). From FGD most of the youngs narrates we afraid to communicate the sexual issue to our family because the family does not push us to discuss such like sexuality and reproductive information. Mostly the family simply punishes their child once the problem is happening but they are not engaging in perversion and education with free sexual health communication( $23,26,30$ and 25 years old youngs).

\section{Sub-theme 1.3 Considering as pushing factors}

"Communicating about the sexual and reproductive issue to a younger child may make them start sexual intercourse because they understand as they are enough mature sexual activities and difficult shape them after they engaged in different bad activities, so better to hide such information to youngers"(47,50 39 years old women). In the first FGD, two boys and four girls, one girl and one boy discussing that early communication on sexual and reproductive health will be very critical to save our future life and directs us in the right way but the parents still do not understand the goal of this kind of communication ( 18 and 22 years old girls and boys respectively). The remaining one boys and three girls also describe that the boys are not discussing sexual health but girls are more likely discussing the issue of sexual; and reproductive health like abstinence, teenage pregnancy, and HIV AIDS.father and mother are not equally discussing sexual health, more than $90 \%$ of sexual communication is taking place by the mother( 23 years old boys and 18,19 and 26 years old girls).

\section{Main them 2 Few communication practices}

\section{Sub-theme 2.1 Trial of communication in an urban area}

Discussing sexuality and reproductive health with a young child is very help full for their future vision achievement. I have a schedule for my young child to communicate freely about reproductive and sexual health. majorly I counsel my child about abstinence before marriage, the dangerousness of sexually transmitted disease mostly HIV ADIS, and the presence of pregnancy but there are many challenges such as shyness, fear, and poor concentration. The other women explain that I always advise my young child about the sexually transmitted disease but my child ignore as simple and another one discuss that I discuss the bad outcome of early sexual intercourse even if my child against to this ideas and refuse to discuss ( 24,32 and 27 years old women).In FGD 1 from the urban sounds explain that we need to 
discuss sexuality and reproductive health but our family especially our father do not create any room to communicate about sexuality rather they consider as badinage or Baudry, even our mother does not give time for communication but some times they counsel our sister about abstinence till finishing her education and sexual intercourse before marriage is being out the norm of the community $(19,29.27$ and 30 years old boys).

\section{Factors associated with a parent to young people communication on a sexual and reproductive health issue}

In binary logistic regression analysis, the variable residence, sex, mother and father education, father and mother occupation, religion, ethnicity, number of children, sex of the parents, age of the parents, attitude, and knowledge of the parents were all significantly associated with a parent to young people communication on a sexual and reproductive health issue at $p<0.05$.

Those variables having a p-value less than 0.05 in bivariate analysis were entered into the multivariable analysis. However, on multivariable analysis, residence, age, sex, knowledge, attitude, number of children, father occupation, father and mother education were identified as significant associated factors with a parent to young people communication.

In this study, the odds of a parent to young people communication on sexual and reproductive health issue among urban reside parents were 2.1 times than those who reside in the rural area (AOR=2.1, $95 \% \mathrm{Cl} 1.15,9.34)$. The parents whose education status primary and secondary education were 2.4 times more communicate than unable to read and write $(A O R=2.4,95 \% \mathrm{Cl} 1.23,4.12)$ as well the education status diploma and above were 6 times more likely communicate as compared with unable to read and write(AOR $=6,95 \% \mathrm{Cl} 5.8,7.9)$ (table-2).

\section{Table 2: Factors associated with a parent to young people communication on a sexual and reproductive health issue 2021}

$[1]^{\star \star \star}$ take care of grand parents

** Shoeshine

\section{Discussion}

This is the community-basedmixed cross-sectional and qualitative study has attempted to identify the challenges and reasons not communicate as well determine the prevalence and an associated factor of a parent to young people communication among parent living with young people (10 -24) years

The prevalence of parent to young people communication on the sexual and reproductive health issue in this study was found to be $11.4 \%$ ( $95 \% \mathrm{Cl}$ : $9.5 \%, 13 \%)$. This was lower than a study done in different part of Ethiopia in Awable words(25.3\%), DeberMarkos(36.9\%),Dire

Dewa(37\%),Harar(28.76\%),EastWelega(32.5\%),Yergalem(59.1\%),Mizan(28.9\%),Hawassa(39\%), Alamata 


\begin{tabular}{|c|c|c|c|c|c|}
\hline \multirow[t]{2}{*}{ Variables } & & \multicolumn{2}{|c|}{$\begin{array}{l}\text { communication of parent } \\
\text { to young about SRH }\end{array}$} & \multirow[t]{2}{*}{$\operatorname{coR}(95 \% \mathrm{Cl})$} & \multirow[t]{2}{*}{$\mathrm{AOR}(95 \% \mathrm{Cl})$} \\
\hline & & Yes n (\%) & No n (\%) & & \\
\hline \multirow[t]{2}{*}{ Residence } & Urban & $90(9 \%)$ & $310(31 \%)$ & $6.96(7.2,8.4)$ & $2.1(1.15,9.34)$ \\
\hline & Rural & $24(3.3 \%)$ & $576(57.6 \%)$ & 1 & 1 \\
\hline \multirow[t]{4}{*}{$\begin{array}{l}\text { Educational } \\
\text { status of the } \\
\text { mother }\end{array}$} & $\begin{array}{l}\text { unable to } \\
\text { read and } \\
\text { write }\end{array}$ & $14(1.4 \%)$ & $372(37.2 \%)$ & 1 & 1 \\
\hline & $\begin{array}{l}\text { read and } \\
\text { write }\end{array}$ & $20(2 \%)$ & $394(39.4 \%)$ & $1.38(1.1,3.5)$ & $2(1.5,3.47)$ \\
\hline & $\begin{array}{l}\text { primary and } \\
\text { secondary }\end{array}$ & $46(4.6 \%)$ & 103(10.3\%) & $11.8(1.6,6.7)$ & $2.4(1.23,4.12)$ \\
\hline & $\begin{array}{l}\text { Diploma and } \\
\text { above }\end{array}$ & $34(3.4 \%)$ & $7(0.7 \%)$ & $12.4(12.3,14.2)$ & $6(5.8,7.9)$ \\
\hline \multirow[t]{3}{*}{ Age } & $23-34$ & $23(2.3 \%)$ & $367(36.7 \%)$ & 1 & 1 \\
\hline & $35-45$ & $34(3.4 \%)$ & $376(37.6 \%)$ & 1.44(1.2, 3.4) & $\begin{array}{l}\text { 1.65(1.16, } \\
4.46)\end{array}$ \\
\hline & $>45$ & $57(5.7 \%)$ & $143(14.3 \%)$ & $6.36(5.44,7.45)$ & $3.22(2.8,4.9)$ \\
\hline \multirow{3}{*}{$\begin{array}{l}\text { Number of } \\
\text { Childs }\end{array}$} & $1-2$ & $24(2.4 \%)$ & $328(32.8 \%)$ & 1 & 1 \\
\hline & $3-5$ & $41(4.1 \%)$ & $457(45.7 \%)$ & $1.22(1.13,2.6)$ & $2(1.50,3.43)$ \\
\hline & $>5$ & $49(4.9 \%)$ & 101(10.1\%) & $6.63(5.4,7.8)$ & $3(2.6,4.74)$ \\
\hline \multirow[t]{4}{*}{$\begin{array}{l}\text { Educational } \\
\text { status of the } \\
\text { father }\end{array}$} & $\begin{array}{l}\text { unable to } \\
\text { read and } \\
\text { write }\end{array}$ & $12(1.2 \%)$ & $304(30.4 \%)$ & 1 & 1 \\
\hline & $\begin{array}{l}\text { read and } \\
\text { write }\end{array}$ & $26(2.6 \%)$ & $468(46.8 \%)$ & $1.4(1.23,4.34)$ & $1.92(1.65,3.71)$ \\
\hline & $\begin{array}{l}\text { primary and } \\
\text { secondary } \\
\text { school }\end{array}$ & $34(3.4 \%)$ & $66(6.6 \%)$ & $13(11.14,15.12)$ & $4.3(1.8,4.56)$ \\
\hline & $\begin{array}{l}\text { Diploma and } \\
\text { above }\end{array}$ & $42(4.2 \%)$ & $48(4.8 \%)$ & $1.77(1.22,2.9)$ & $2.5(1.6,4.13)$ \\
\hline \multirow[t]{2}{*}{ Sex } & Male & $72(7.2 \%)$ & $434(43.4 \%)$ & $1.78(1.40,3.7)$ & $2.4(2.11,4.33)$ \\
\hline & Female & $42(4.2 \%)$ & $452(45.2 \%)$ & 1 & 1 \\
\hline \multirow[t]{2}{*}{ Knowledge } & $\begin{array}{l}\text { inadequate } \\
\text { knowledge }\end{array}$ & $24(2.4 \%)$ & 676(67.6\%) & 1 & 1 \\
\hline & $\begin{array}{l}\text { adequate } \\
\text { knowledge }\end{array}$ & $90(9 \%)$ & $210(21 \%)$ & $12(10.21,14.12)$ & $3.8(2.7,6.34)$ \\
\hline
\end{tabular}




\begin{tabular}{|c|c|c|c|c|c|}
\hline \multirow[t]{2}{*}{ Attitude } & poor attitude & $42(4.2 \%)$ & $570(57 \%)$ & 1 & 1 \\
\hline & good attitude & $72(7.2 \%)$ & $316(31.6 \%)$ & $3.09(2.4,6.23)$ & $2.2(1.44,4.32)$ \\
\hline \multirow{4}{*}{$\begin{array}{l}\text { Occupational } \\
\text { status of the } \\
\text { mother }\end{array}$} & house wife & $40(4 \%)$ & $472(47.2 \%)$ & 1 & 1 \\
\hline & $\begin{array}{l}\text { gov.t and } \\
\text { private } \\
\text { employee }\end{array}$ & $23(2.3 \%)$ & $25(2.5 \%)$ & $10.85(9.55,13.38)$ & $3.39(2.78,8.64)$ \\
\hline & Merchant & $20(5.1 \%)$ & 19919.9\%) & $1.18(2.27,9.38)$ & $1.97(0.62,4.26)$ \\
\hline & $\begin{array}{l}\text { Daily labor } \\
\text { and others }\end{array}$ & $21(2.1 \%)$ & $200(20 \%)$ & $1.23(2.1,6.9)$ & $1.87(0.56,12$ \\
\hline \multirow{4}{*}{$\begin{array}{l}\text { Occupational } \\
\text { status of the } \\
\text { father }\end{array}$} & Farmer & $50(5 \%)$ & $455(45.5 \%)$ & 1 & 1 \\
\hline & $\begin{array}{l}\text { gov.t and } \\
\text { private } \\
\text { employee }\end{array}$ & $26(2.6 \%)$ & $38(5.9 \%)$ & $6.23(7.61,8.06)$ & $4.20(3.03,6.17)$ \\
\hline & Merchant & $23(2.3 \%)$ & $195(19.5 \%)$ & $1.07(0.71,7.29)$ & $.36(.08,1.61)$ \\
\hline & $\begin{array}{l}\text { Daly labor } \\
\text { and others** }\end{array}$ & $15(1.5 \%)$ & 198(19.8\%) & $0.68(0.99,3.7)$ & $09(1.6,7.8)$ \\
\hline
\end{tabular}

(68.2\%)and Mekelle town(57.6\%) ([17-21, 26-34]. The possible explanation for this can be, all those studies take place in the urban part of the country in which those who reside in the urban have got different information as they are near to media as well they are more educated. Moreover, there is a study set up a difference in which, this study is a community-based study on parents whereas the other studies were institutionally based on students and the youngs be the night students were more communicate about sexual and reproductive health than the day time students.

In this study parents, who reside in the urban were 2.1 times more communicate aboutsexual and reproductive health issues with their young as compared with the parents who reside in the rural area $(A O R=2.1,95 \% \mathrm{Cl} 1.15,9.34)$. The reason may be the parents reside in the rural area are not exposed to different media information, not mostly educated and they are busy in their work This is supported by a study done Awabele woreda, Alamata and East Wolga[17, 21, 24, 26, 31]

This study shows that husbands were 2.4 times more communication with their young about sexual and reproductive health issues than wives( $\mathrm{AOR}=2.4,95 \% \mathrm{Cl} 2.11,4.33)$. This is explained as, in this area husbands and wives may not have an equal chance for accessing and discussing such sexual and reproductive health issues. Moreover, wives are busy in the household to care for all the family.

This is supported by a study done in Awabele woreda[17]. However not supported by the study done in Alamata and Mekelle town [26, 30, 31].

Participant's having adequate knowledge were 3.8 times more communicate with their young people about sexual and reproductive health issue than who having inadequate knowledge 
$(A O R=3.8,95 \% \mathrm{Cl} 2.7,6.34)$ as well those having good attitude were 2.2 times more communicate with the young people about sexual and reproductive health issue as compared with those having poor attitude(AOR=2.2,95\% $\mathrm{Cl} 1.44,4.32)$. The reason may be if peoples are knowledgeable and having a good attitude, they believe that as routinely discuss with their young children. This is supported by a study done in Harar and Alamata[19, 26].

Regarding educational status, husbands whose education status diploma and above were 2.5 times more communicate about SRH issue as compared with unable to read and write parents ( $\mathrm{AOR}=2.5,95 \% \mathrm{Cl} 1.6$, 4.13). and those attending primary and secondary education were 4.3 times more communicate than unable to read and write husbands $(\mathrm{AOR}=4.3,95 \% \mathrm{Cl} 1.8,4.56)$. the maternal educational status primary and secondary education were 2.4 times more communicate than unable to read and write(AOR $=2.4,95 \%$ $\mathrm{Cl} 1.23,4.12)$ and those women educational status diploma and above were 6 times more likely to communicate as compared to unable to read and write $(A O R=6,95 \% \mathrm{Cl} 5.8,7.9)$. The reason may be educated peoples can easily understand the effect of a parent to young people communication.

Thesis supported by a study done in Harar, Hawassa, East Wolega, Mekelle, Alamata, and Awabel woreda $[17,19,21,26,27,30]$.

In this study, the parents having family size five and above were 3 times more communicate about SRH issue with their young than having a family size three and less ( $\mathrm{AOR}=3,95 \% \mathrm{Cl} 2.6,4.74)$. and the parents in the age range of 35-45 and above were 3.22 times more communicate as compared with ageless than 34 years old $(A O R=3.22,95 \% \mathrm{Cl} 2.8,4.9)$ The possible reason may be as parents family member increase and they become mature, they easily predict the outcome of poor communication between family members. This is supported in a study done DeberMarkos town[28].

\section{Conclusion}

Based on the finding obtained in this study, Parent to young people's communication on the sexual and reproductive health issue in the north Gondar Zone was low as compared to other studies done in a different part of Ethiopia. The challenge and reasons not discussing aboutsexuality and reproductive health were identified as fear of both the parents and youngs, not acceptable by the community, considering as pushing factors and clutures of the community not allow to communicate. Variables: residence, sex, knowledge, attitude, and Father's and mother's educational status, number of children, and age of the parents were significantly associated with a parent to young people communication on the sexual and reproductive health issue.

\section{Abbreviations}

AIDS. .Acquired Immunodeficiency Syndrome

HEW. Health Extension Worker 
$\mathrm{HH}$. House Hold

HIV. ..Human Immunodeficiency Virus

$\mathrm{MOH}$ ..Ministry Of Health

PI Principal Investigator

RH. Reproductive Health

SDG. Sustainable Development Goal

SRH. Sexual and Reproductive Health

STI. Sexual Transmitted Infection

WHO World Health Organization

\section{Declarations}

\section{Ethics approval and consent to participate}

An ethical clearance letter was obtained From the Midwifery department, under the delegation of the MizanTepi University, and submitted to the north Gondar zone administrative unit toobtained a permission letter. Then the Zone given written a permission letter to the concerned bodies in the study set up and informed consent was obtained from respondents after giving them information about the purpose of the study, confidential and anonymous

\section{Consent for publication}

Not applicable for this study

\section{Availability of data and material}

The datasets used and/or analyzed during the current study are available from the corresponding author on reasonable request.

\section{Competing interests}

The authors declare that they have no competing interests.

\section{Funding}

The authors have not received any funding or benefits from the industry or elsewhere to conduct this study. 


\section{Authors' contributions}

All the authors have a significate contribution in conception, selecting a design, data collection as well as analysis and interpretation of data and in all these areas; took part in drafting, revising, or critically reviewing the article; gave final approval of the version to be published; have agreed on the journal to which the article has been submitted; and agree to be accountable for all aspects of the work.

\section{Acknowledgment}

First and foremost, our heartfelt goes to the MizanTepi University research committee for their permission letter and the health science staff for their continuous upkeeping. Our thanks likewise go to southwest region administrators and different zones and woreda administrators in Northwest Ethiopia for their permission and uninterrupted follow-up and health extension workers for their valuable information and are inside us during the data collection period. Finally, we thank you to our data collector and participants for their cooperative and time

\section{Authors' information}

YohannesWobie Wondimhunegn, email:yohanneswobie@gmail.com

\section{Alemnew Wale Tegegne, email: walealemnew@gmail.com}

Aychew Kassie Gidafie,email:aychewkassie055@gmail.com

Dessalegn Girma Mamo, email:desegir@gmail.com

Abinet Abebe Zewdu,emailabinetabebe.21@gmail.com

ZinieAbita Mengie, email:zinieabita@gmail.com

Bezie Kebede Zelalem, email: beza.kebede21@gmail.com

\section{References}

1. Ethiopia, F.D.R.o. and M.o. Health, Adolescent and Youth Reproductive Health. 2011.

2. IPPF_UNFPA_Global SRH Package Men And Boys, Global Sexual and Reproductive Health Service Package. 2017: Geneva.

3. Othman, A., et al., Parent-child communication about sexual and reproductive health: perspectives of Jordanian and Syrian parents. Sexual and Reproductive Health Matters, 2020. 28(1): p. 1758444.

4. Population Services International, The Socio-cultural Drivers ofSexual and Reproductive Healthfor Adolescent Girls in Ethiopia. 2016. 
5. WHO, Consolidated guideline on sexual and reproductive healthand rights of women living with HIV. 2017.: Geneva.

6. New York City and Health Department, SEXUAL AND REPRODUCTIVEHEALTH CAREBEST PRACTICES FORADOLESCENTS AND ADULTS. 2016.

7. Addis Ababa statistical agency, Census in Ethiopia. 2013/14.

8. WHO, $A$ WHO guideline for emergency risk communication (ERC) policy and practice. 2017: Geneva.

9. $\mathrm{MOH}$, national reproductive health strategy of Ethiopia 2007-2015.

10. Aarø, L.E., et al., Promoting sexual and reproductive health among adolescents in southern and eastern Africa (PREPARE): project design and conceptual framework. BMC Public Health, 2014. 14: p. 5454.

11. Tebekaw, Y., B. Aemro, and C. Teller, Prevalence and determinants of unintended childbirth in Ethiopia. BMC Pregnancy and Childbirth, 2014. 14: p. 326.

12. Gelaye, A.A., K.N. Taye, and T. Mekonen, Magnitude and risk factors of abortion amongregular female students in Wolaita SodoUniversity, Ethiopia. BMC Women's Health, 2014.

13. Bereket Yohannes, T.G. and M. Tarekegn, Prevalence-And-Associated-Factors-Of-SexuallyTransmitted-Infections-Among-Students-Of-Wolaita-Sodo-University-Southern-Ethiopia. INTERNATIONAL JOURNAL OF SCIENTIFIC \& TECHNOLOGY RESEARCH, 2013. 2(2).

14. Kassa, G.M., et al., Risky Sexual Behaviors and Associated Factors among Jiga High School and Preparatory School Students, Amhara Region, Ethiopia. International Scholarly Research Notices, 2016. 2016: p. 4315729.

15. Hailay Gebremichael, W.T., Mussie Alemayehu, Henock Gebremedhn, Daniel Nigussie, MAGNITUDE AND PREDICTORS OF SELF-REPORTED SEXUALLYTRANSMITTED INFECTIONS AMONG SCHOOL YOUTH IN BAHIR-DAR NORTHWEST ETHIOPIA. EthiopMed J, 2017. 55(2).

16. Shiferaw, Y., et al., Assessment of knowledge, attitude and risk behaviors towards HIV/AIDS and other sexually transmitted infection among preparatory students of Gondar town, northwest Ethiopia. BMC Research Notes, 2011. 4: p. 505-505.

17. Atitegeb Ayehu, T.K., and G. Hailu, Young people's parental discussion aboutsexual and reproductive health issues andits associated factors in Awabel woreda, Northwest Ethiopia. BioMed Central, 2016 13(19). 
18. Ayalew, M., B. Mengistie, and A. Semahegn, Adolescent-parent communication on sexual and reproductive health issues among high school students in Dire Dawa, Eastern Ethiopia: a cross-sectional study. Reproductive Health, 2014. 11: p. 77.

19. Yadeta, T.A., H.K. Bedane, and A.K. Tura, Factors Affecting Parent-Adolescent Discussion on Reproductive Health Issues in Harar, Eastern Ethiopia: A Cross-Sectional Study. Journal of Environmental and Public Health, 2014. 2014: p. 7.

20. Sisay Shewasinad, Z.A., and G.B. Kiros Yeshitla, Sophonias Negash, Communication on Sexual andReproductive Health Issues among Mizan Secondary andPreparatory School Students with Parents, Mizan Town, Ethiopia. American Journal of Health Research, 2017. 5(5): p. 131-140.

21. Tesso, D.W., M.A. Fantahun, and F. Enquselassie, Parent-young people communication about sexual and reproductive health in E/Wollega zone, West Ethiopia: Implications for interventions. Reproductive Health, 2012. 9: p. 13-13.

22. Dessie, Y., Y. Berhane, and A. Worku, Parent-Adolescent Sexual and Reproductive Health Communication Is Very Limited and Associated with Adolescent Poor Behavioral Beliefs and Subjective Norms: Evidence from a Community Based Cross-Sectional Study in Eastern Ethiopia. PLOS ONE, 2015. 10(7): p. e0129941.

23. Feleke, W. and G. Samuel, REPRODUCTIVE HEALTH. 2008, Addis Ababa: University of Gondar.

24. Aw, T. and A. Wale, Parent to Young Communication on Sexual and Reproductive Health and Associated Factors among Parents Living with Young in Dera Woreda, North West Ethiopia 2018. 2019.

25. Virginia, C.o., Definition

of"parentavialbelhttps://law.lis.virginia.gov/vacode/title22.1/chapter13/section22.1-213.1/access on $26 / 2 / 2018$

26. Nurilign Abebea, G.M., Parent-Adolescent Communication on Sexual andReproductive Health Issues and Associated Factors in AlamataHigh School, Northern Ethiopia. international Journal of Sciences: Basic andApplied Research (IJSBAR, 2013. 7(1).

27. Sailaja B, N.C., Barriers of Discussion Concerning Sexual and ReproductiveHealth Issues Among Adolescents and Parents, Hawassa,SNNPR, Ethiopia. Sailaja Busi. Biomed J Sci \& Tech Res, 2017. 1(7).

28. Shiferaw, K., F. Getahun, and G. Asres, Assessment of adolescents' communication on sexual and reproductive health matters with parents and associated factors among secondary and preparatory schools' students in Debremarkos town, North West Ethiopia. Reproductive Health, 2014. 11: p. 2-2.

29. Zemenu Yohannes and B. Tsegaye, Barriers of Parent-Adolescent Communication on Sexual and ReproductiveHealth Issues among Secondary and Preparatory School Students inYirgalem, Town, South Ethiopia. Family Medicine \&Medical Science Research, 2015. 4(4). 
30. Zemenu Yowhanes, H.B.D.H., mekell town school. Global Journal of Medical Research: EGynecology and Obstetrics, 2016 16(2).

31. Eshete, A. and S. Shewasinad, Adolescent-Parent Communication on Sexual and Reproductive Health issues in Ethiopia: A Systematic Review and Meta-analysis. Ethiop J Health Sci, 2020. 30(5): p. 817-828.

32. Mihretie, G.N., et al., Young-parent communication on sexual and reproductive health issues among young female night students in Amhara region, Ethiopia: Community-based cross-sectional study. PLOS ONE, 2021. 16(6): p. e0253271.

33. Sagnia1, P.I.G., E.P. Gharoro2, and A.R. Isara3, Adolescent-parent communication on sexual andreproductive health issues amongst secondary school students in Western Region 1 of The Gambia. African Journal of Primary Health Care \& Family Medicine, 2020. 12(1).

34. Wudineh, K.G., F.A. Chekole, and A.A. Tesfu, Adolescent-parent communication on sexual and reproductive health issues and associated factors among secondary school students in Woreta town, Northwest Ethiopia: An institutional-based cross-sectional study. Heliyon, 2021. 7(3): p. e06528.

\section{Figures}

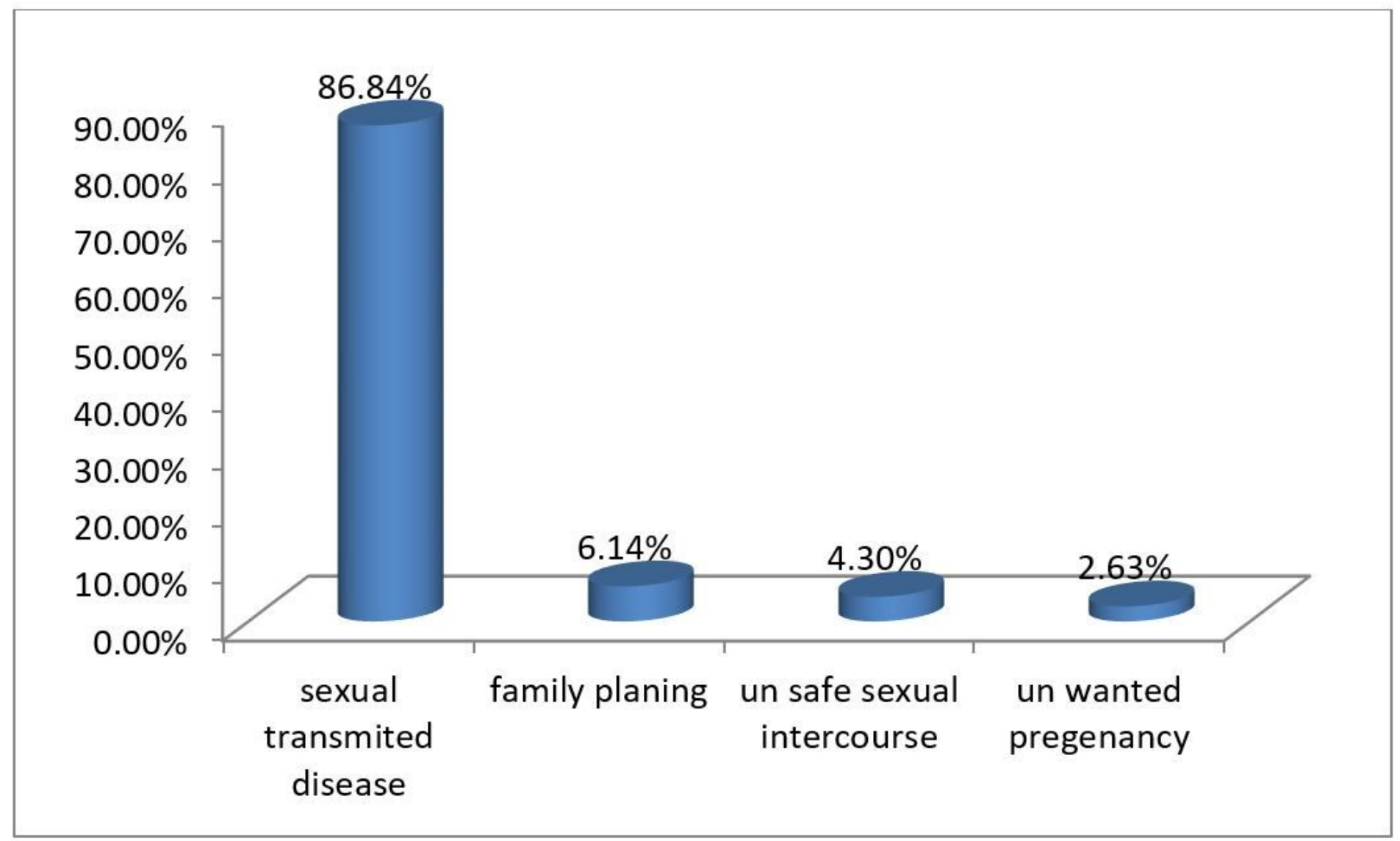


patterns of parent to young people communication on sexual and reproductive health in North Gondar Zone, North west Ethiopia 2021

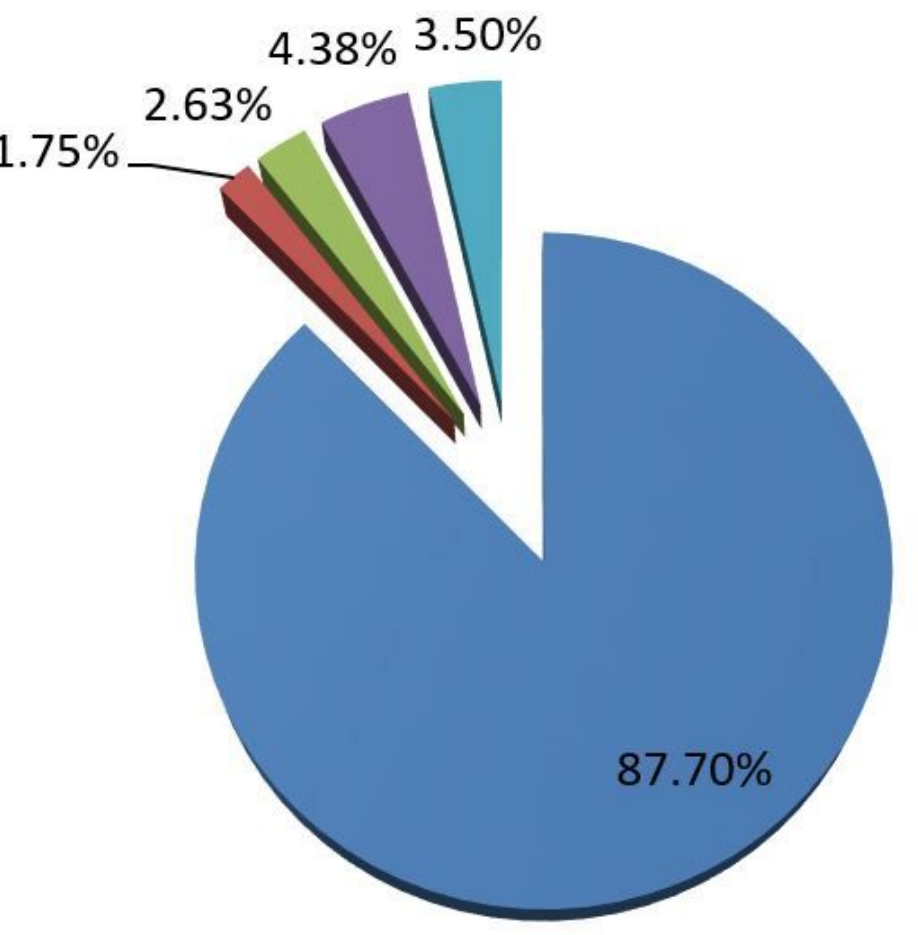

abstinences

- Long acting family planning

Condom use

Injectable

$\mathrm{COC}$

\section{Figure 2}

parent to young people communication on family planning in North Gondar zone, North West Ethiopia 2021 


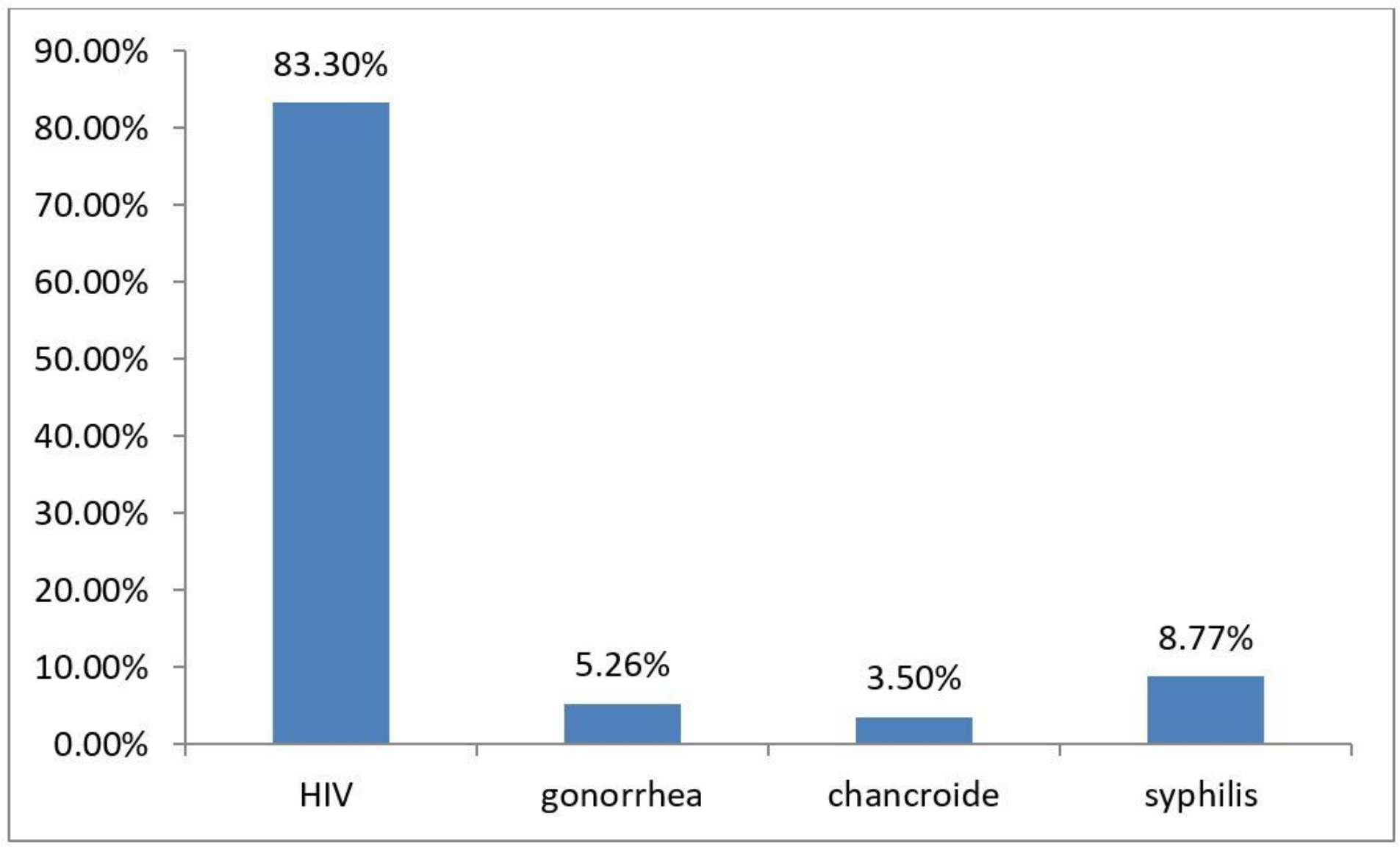

Figure 3

parent to young people communication on sexual transmitted diseases in North Gondar zone, North West Ethiopia 2021 


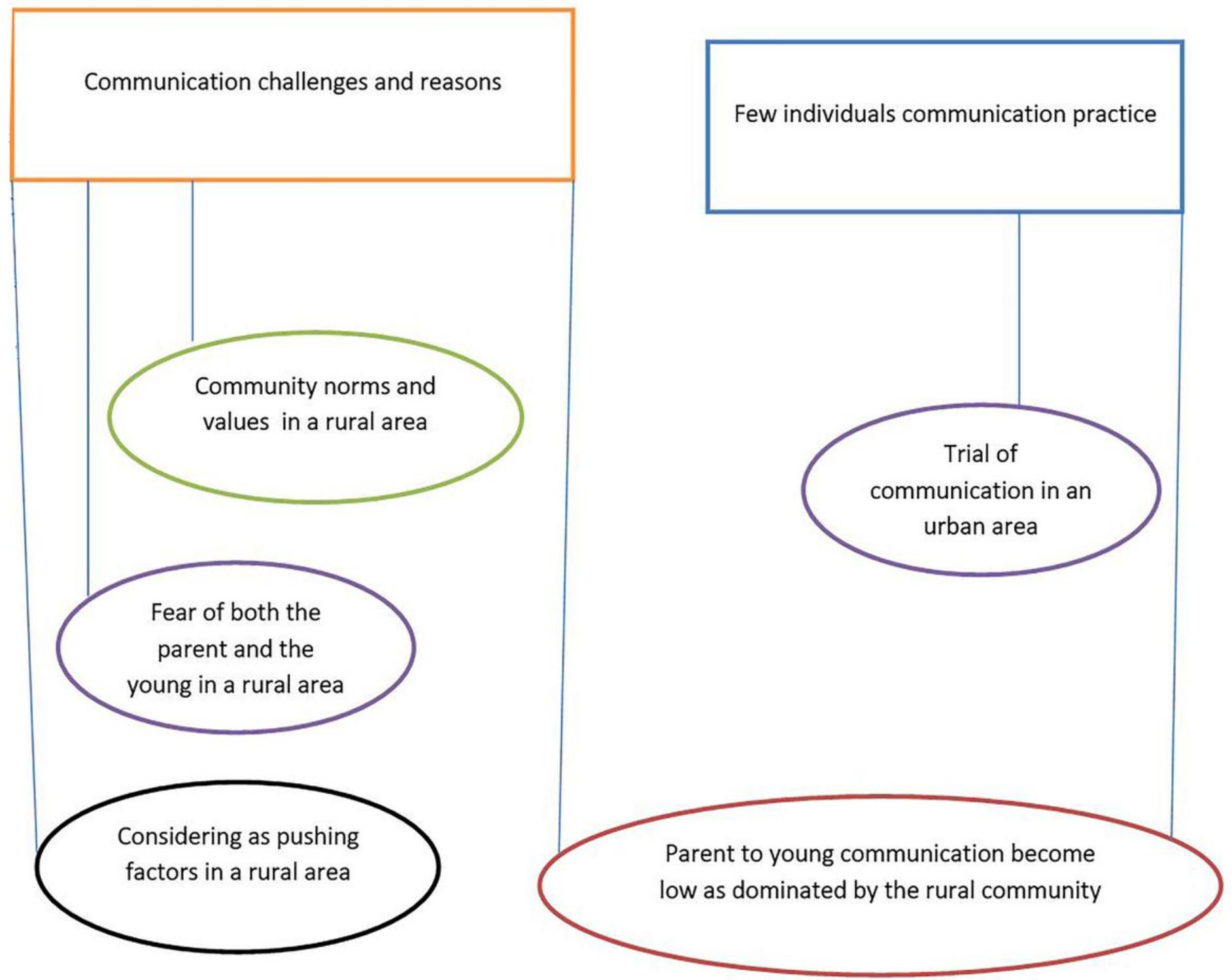

Figure 4

Thematic map on traditional birth attendance regarding the care and integration with health facilities in West Omo one, 2021 